\title{
What the Poor do to Survive. (Im) Politeness and Classism in Brazilian Twitter
}

\author{
Ana Larissa Adorno Marciotto Oliveira* \\ Marisa Carneiro Mendonça** \\ Gustavo Ximenes Cunha***
}

\begin{abstract}
Research on (im)politeness (CULPEPER; HAUGH; KÁDÁR, 2017) has widely replaced the term 'culture' with the concept of 'community of practice', or by the umbrella-like term 'interactional practices' (MILLS, 2015, p. 30; MILLS; KÁDÁR, 2011). From this view, this study aims at examining hashtags related to the topic \#What the poor do to survive, which include \#thingspoorpeopledo (\#coisasquepobrefaz) and three other variants, \#thatispoverty (\#pobrezaéissoai), \#poverty (\#pobreza), and \#poor (\#pobre). To do that, data were collected from Twitter posts published in Brazilian Portuguese and listed among the trending topics in 2017 and in 2019. After we collected the posts and their accompanying hashtags, a qualitative analysis was performed, aiming at describing and categorizing the impoliteness strategies identified. In this phase of the research, over 400 tweets containing hashtags were analyzed. We found that the hashtags investigated primarily aimed at exchanging humorous messages, mostly associated with social class division in Brazil. At the same time, our findings also showed that the hashtags signalled a recurrent verbal behavior shared by a community of practice assembled under a tag (BRUNS; BURGESS, 2011; STARBIRD; PALEN, 2011).
\end{abstract}

\footnotetext{
* Universidade Federal de Minas Gerais (UFMG). Docente da Faculdade de Letras e do Programa de Pós-Graduação em Estudos Linguísticos da UFMG. Bolsista de Produtividade do CNPq (nível 2). Processo: 309492/2020-3. ORCID: https://orcid. org/0000-0003-1857-0207.

** Universidade Federal de Minas Gerais (UFMG). Docente da Faculdade de Letras e do Programa de Pós-Graduação em Estudos Linguísticos da UFMG. ORCID: https://orcid.org/0000-0003-1217-2160.

*** Universidade Federal de Minas Gerais (UFMG). Docente da Faculdade de Letras e do Programa de Pós-Graduação em Estudos Linguísticos da UFMG. Bolsista de Produtividade do CNPq (nível 2). Processo: 304244/2019-8. ORCID: https://orcid. org/0000-0001-9953-1204.
} 
Additionally, our data demonstrated that hashtags had a dual purpose: while they employed mock impoliteness and sarcasm to reinforce valid social norms, they also promoted a jocular debate on classism and ideology in Brazil.

Keywords: Linguistic impoliteness. Hashtags. Classism. Mockery.

\title{
O que os pobres fazem para sobreviver. (Im)Polidez e classismo no Twitter brasileiro
}

\begin{abstract}
Pesquisas sobre (im)polidez (CULPEPER; HAUGH; KÁDÁR, 2017) substituíram amplamente o termo 'cultura' pelo conceito de 'comunidade de prática', ou pelo termo guardachuva 'práticas interacionais' (MILLS, 2015, p. 30; MILLS; KÁDÁR, 2011). Sob essa ótica, este estudo tem como objetivo examinar as hashtags relacionadas ao tema \#O que os pobres fazem para sobreviver, que incluem \#coisasquepobrefaz e três outras variantes, \#pobrezaéissoaí, \#pobreza e \#pobre. Para isso, foram coletados dados de postagens do Twitter, publicadas em português do Brasil, e listadas entre os trending topics em 2017 e em 2019. Depois de coletar as postagens e as hashtags que as acompanhavam, foi realizada uma análise qualitativa do corpus, com o objetivo de descrever e de categorizar as estratégias de impolidez observadas. Nessa fase da pesquisa, mais de 400 tweets contendo hashtags foram analisados. Os resultados mostraram que hashtags tinham como objetivo principal a troca de mensagens humorísticas, associadas à divisão de classes no Brasil. Ao mesmo tempo, nossos dados demonstraram que as hashtags também sinalizavam um comportamento verbal recorrente, compartilhado por uma comunidade de prática, reunida sob uma tag (BRUNS;
\end{abstract}


BURGESS, 2011; STARBIRD; PALEN, 2011). Além disso, as hashtags tinham um propósito duplo: enquanto empregavam impolidez e sarcasmo para reforçar normas sociais válidas, também promoviam um debate jocoso sobre classismo e ideologia no Brasil.

Palavras-chave: Impolidez linguística. Hashtags. Classismo. Deboche.

Recebido em: 09/02/2021 // Aceito em: 26/02/2021. 


\section{An overview of the study}

Twitter hashtags are opinionated text genres pervasive on Twitter (YANG, et al. 2012; OLIVEIRA; CARNEIRO, 2018). This study aims to examine hashtags related to the social class dispute in Brazil. Of particular interest in this research are hashtags related to the topic What the poor do to survive, which include \#thingspoorpeopledo (\#coisasquepobrefaz), and three other variants, \#thatispoverty (\#pobrezaéissoai), \#poverty (\#pobreza), and \#poor (\#pobre). These hashtags primarily aimed at exchanging humorous messages, mostly associated with lowincome class habits and social class division. While doing this, these hashtags also assembled users, forming a 'community of practice' under a tag (BRUNS; BURGESS, 2011; MILLS; KÁDÁR, 2011).

Recent research on (im)politeness (MILLS; KÁDÁR, 2011; CULPEPER; HAUGH; KÁDÁR, 2017) has widely replaced the term 'culture' by the concept of 'community of practice', or by the umbrella-like terms 'interactional practices'. This notion encompasses 'a loosely defined group of people who are mutually engaged in a particular task'. (MILLS, 2015, p. 30). In the framework proposed by Kienpointer and Stopfner (2017), certain linguistic expressions, codified as impolite in some cultures or communities of practice, can be interpreted differently, depending on the dominant discourse. This framework reinforces that the discursive-cultural dimension is always decisive for interpreting what is considered impolite and aggressive in a given community of practice. From this perspective, we make a case that the hashtags analyzed employed mockery as an impoliteness strategy to promote a digital debate 
on classism in Brazil. Considering this research panorama, we will discuss the theoretical framework that underpins the study in the next section.

\section{Mockery as a strategy of impoliteness}

Research on linguistic impoliteness encompasses a variety of social relations. From Bousfield's perspective (2008), impoliteness is defined as the intentional communication of Face Threatening Acts (FTAs) (BROWN; LEVINSON, 1987), which are usually carried out either in unmitigated forms or with deliberate aggression. For Culpeper (2005) e Culpeper, Haugh and Kádár, (2017), impoliteness can be identified when: (1) the speaker intentionally communicates the attack to the face, or (2) the listener perceives the behavior as intentional, or when there is a combination of (1) and (2). In almost all available models, impoliteness is related to the emergence of negative emotions and face loss (GOFFMAN, 1973). Impoliteness can also be manifested directly (bald on record) or indirectly (off record). When bald on record, the face threat is communicated directly, unambiguously, and concisely. When indirect (off record), face attack is carried out employing an implicature, which occurs in such a way that the speaker's offensive verbal behaviour typically surpasses any other rational interpretation.

As for positive impoliteness, it refers to strategies that attack the hearer's positive face, that is, his wants and needs. This process happens when the speaker ignores, excludes, and uses markers of disinterest or when she employs obscure language or taboo words targeted at the interlocutor or a third party. On the counterpart of positive impoliteness, but within the same domain, 
negative impoliteness consists of strategies intended to damage the interlocutor's negative face or a third party's. It encompasses language intended to threaten, despise, and ridicule, as well as language used to invade the other person's space by associating him with explicitly negative aspects, or by putting his debt in focus.

Particularly concerning the offense, Haugh (2015, p. 37) suggests that it 'can be understood as a social action initiated by the addressee in which he interprets the actions, or the conduct of the interlocutor (or some other person or groups of persons) as offensive'. For the author, while being a pragmatic act, an insult is restricted by the type of activity in which it arises and by the immediate context. From this perspective, sarcasm, irony, and mockery are described as meta-strategies of impoliteness since they constitute potential FTAs, frequently understood as insincere and/or as forms of power abuse.

More specifically, Culpeper (1996) describes the phenomenon as a kind of impoliteness that 'remains on the surface, since it is understood that it is not intended to offend'. (CULPEPER, 1996, p. 352). Consequently, offenses are more likely to be interpreted as banter when intended for interlocutors that the speaker likes. Moreover, Culpeper (1996) claims that mockery or banter can also occur in ritualized interactions, as a 'language game' structured in a speech event form (LABOV, 1972). Along these lines, mockery can be understood as a form of untrue offense taken as such due to the kind of shared knowledge within a group. Hence, mock impoliteness's primary effect may be to reinforce in-group solidarity (CULPEPER, 1996). Similarly, mock impoliteness may function as a 'safety valve' (CULPEPER, 2011, p. 211) in contexts where interlocutors' aggressive behaviour seems to be the norm. As Leech (2014, p. 241) puts it: 
Banter tends to occur almost ritualistically in certain communities of practice where individuals undergo emotional pressure, for example, in hospitals or sports team events. Emotional pressure can reach a breaking point and result in uncontrolled aggression and violence. It seems likely that, in such situations, banter has a positive function in allowing aggression to be expressed, but also in defusing its violent effects by promoting an atmosphere of friendly jocularity.

Studies on (im)politeness traditionally adopted a pragmatic perspective of analysis, mainly focused on the speaker's strategies to soften speech act aggressiveness. From this point of view, issues related to the broader context motivating these strategies use were often neglected. When these aspects were considered, they were typically analyzed from a cultural anthropological perspective, notably associated with descriptions of cultures, which resulted in a fairly homogeneous characterization of how members of different cultures behaved, such as Americans, Indians, or Japanese.

In more recent decades, however, there has been an increasing interest in associate (im)politeness with broader sociohistorical issues to explore specific (im)politeness strategies. This perspective connects to the 'communities of practice' definition, which, in turn, encompasses an account of material conditions within those communities (MILLS; KÁDÁR, 2011; KIENPOINTER; STOPFNER, 2017).

From this point of view, there has been a general interest in developing studies on (im)politeness from a more critical perspective regarding social sciences in general and language use. Thus, rather than studying 'typical' verbal behaviour in a given culture, these studies have focused more on identifying strategies of (im)politeness employed in specific situations and 
on how they may reflect broader social disputes structuring social space and placing different segments of society in positions of conflict, dominance, consent, and dissent (MILLS, 2003; OSTERMANN, 2006; SOTO; ARANCIBIA, 2017; BLITVICH, 2018; GRAINGER, 2018; CUNHA; TOMAZI, 2019).

Along these lines, Kienpointer and Stopfner (2017) also argue that there are at least two ways in which the ideological component can be identified in classical Politeness Theory (BROWN; LEVINSON, 1987): (a) the (alleged) rationality of speakers, associated with the observed results homogeneity, and (b) the (supposed) existence of a crystallized and universal model for (im)politeness. From this perspective, Kienpointer and Stopfner (2017) discuss how, in the framework proposed by Brown and Levinson (1987), politeness is conceived of as strategic, rational, and operating following linear Western thought.

In opposition to this homogenizing view of politeness, a growing research tradition (KÁDÁR; HAUGH, 2013; KIENPOINTER; STOPFNER, 2017) has shown that Brown and Levinson's model, though still valid and comprehensive, may be biased towards politeness. According to this tradition, impoliteness is not simply a deviation from politeness, nor is it merely an effect of strong negative emotions. Similarly, impoliteness is not always seen as the marked, exceptional politeness counterpart. In some cultures and specific institutional contexts, impoliteness can even be the norm (CULPEPER; HAUGH; KÁDÁR, 2017).

In sum, the use of expressions of direct negative criticism and the production of contemptuous comments usually characterize impoliteness and offense to the interlocutor. In posts containing 
hashtags analyzed here, however, we are interested in speculating how/if mock impoliteness was employed in hashtags to create humor, reinforce in-group solidarity (CULPEPER, 1996), and challenge social norms. In the following section, we will discuss social status, classism, and ideology relevant to this study.

\section{Social status, classism and ideology}

As Goffman (1951, p. 294) claims, social status 'may be ranked on a scale of prestige, according to the amount of social value that is placed upon it relative to other statuses in the same sector of social life'. For the author, individuals may be rated on a scale of prestige, depending on how close they are to the ideal behaviour expected, and to status symbols that they display. Status symbols, for Goffman, are 'the cues that select for a person the status that is to be imputed to him and how others are to treat him'. (GOFFMAN, 1951, p. 295). From this perspective, any item of a person's social behaviour may be considered as a sign of his social position. Because social classes, as well as individual members, may sometimes rise or fall, concerning their 'relative wealth, power, and prestige'. (GOFFMAN, 1951, p. 297), status symbols play an important role in reaffirming the established status. They impede the social emergence of those who have recently acquired power or wealth, while they hold back the fall of those who have lost it. By means of displaying status symbols, continuity of a social status tradition may be assured, and effects of social privilege may remain untouched.

In Brazil, social, racial, and gender privilege have been primarily explained as a result of inequalities stemming from slavery, as well as historical processes of 'uneven development 
across and within Brazilian regions'. (LAYTON; SMITH, 2017, p. 54). Despite efforts to promote Brazil as a 'racial democracy' (c.f. FREYRE, 1973; SILVA, 2012), social class, gender, and race discrimination are immanent in the country (LOVELL, 2006). Along these lines, a study conducted by Telles and Bailey (2013) has shown that many Brazilians indicated 'discrimination' as a reason to explain why Afro-Brazilian descendants remained more flawed while being the majority of the population. Discrimination towards race, class, and gender in Brazil is also manifested in sarcasm, mockery, and verbal insult, not only within face-to-face interactions but also in social media exchanges, as we will see in the different sections of this study.

The common notion of ideology is that of a 'pejorative ring' (EAGLETON, 2014, p. 11), suggesting a distorted perspective caused by wrong preconceptions, manipulation, propaganda, and power. The term 'ideology' is typically employed in everyday conversation as a stigma attributed to others who are 'unable, or unwilling, to realize how things really are' (KIENPOITNER; STOPFNER, 2017). In this view, ideology and classism can be manifested in pejorative denominations of low-income classes, such as 'redneck', 'trash', 'riff-raff', 'proles', 'the unwashed masses. In Brazilian Portuguese, ralé, povão, prole, grande massa are their equivalent terms. These expressions imply 'generalized negative assumptions about the habits, manners and living standards of the social groups referred to' (KIENPOITNER; STOPFNER, 2017, p. 87). Moreover, classism can also involve categorizing low-income classes' communicative behavior (and ethnic minorities) as being generally rude, primitive, and uneducated (MILLS, 2015, p. 149), while upper-classes are often associated with civility and good upbringing, and with superior social status. 
As a reaction to classism, working-class people may coin mocking phrases targeted at the so-called 'over-refined' middleclass politeness (KÁDÁR; MILLS, 2011). Similarly, 'outsiders' and 'social outcasts' sometimes develop a kind of "antilanguage", through which norms and values of dominant groups may be reversed. This language is only partially comprehensible for most speakers, and hence it is often experienced and assessed as rude and uneducated (KÁDÁR; MILLS 2011).

Considering this theoretical panorama on social status, classism, and ideology, we set off to discuss how it may be made manifest in the digital environment through the use of hashtags.

\section{Twitter hashtags}

Twitter is a communication platform that enables users to broadcast 280-character messages, the tweets, to groups of other users who subscribe to their accounts, the followers. For tweeters, whose accounts are not explicitly set as private, every tweet is posted to the public and in a searchable timeline (STARBIRD; PALEN, 2011).

Length restrictions on updates imposed by Twitter led to the development of techniques for making the most of such limited affordances. It is common to find abbreviations and omissions, numbers and letters for homophonic words and morphemes (e.g. '4' instead of 'for'), shortening of words and omission of subjects, copula verbs, articles, and prepositions (CRYSTAL 2011). Such length restrictions, and strategies used to cope with them, entail that the reader collaboratively constructs the intended messages with their author. Thus, tweets typically involve hashtags since they contribute to activating contextual clues, helping specific meanings be more effectively communicated (YANG et al. 2012; SCOTT, 2015). 
Hashtags have emerged from CMC (Computer-Mediated Communication) context primarily to facilitate navigation. By employing a 'user-defined index term of content', a hashtag assembles relevant topics and events while maximizing the potential of information retrieval'. (YANG, 2012, p. 4). The fact that hashtags help to identify users participating in a relevant discussion makes them effective strategies to screen out information and enable users to narrow down their search focus. Apart from being topic organizers, Starbird and Palen (2011) showed that hashtags also operate as a basis for organizing volunteering work activities, particularly those following major natural disasters, for example, the 2010 earthquake in Haiti (STARBIRD; PALEN, 2011). As part of this social networking function, Starbird and Palen (2011) identified hashtags as a means to form 'bonds and to create a feeling of community. (STARBIRD; PALEN, 2011, p. 3). Hence, the use of hashtags surpasses content bookmarking. As a result, a hashtag serves as a particular community symbol. Hashtags enable users to identify and participate in online chats originated by tag. As Starbird and Palen (2011) state, a hashtag puts together a virtual community of users with the same background and interest or involved in the same task.

Moreover, hashtags engage participants in discussions while they also connect them with a shared text outside Twitter. According to Bruns and Burgess (2011), hashtag communities indicate that users are not merely tweeting into the hashtag stream; they also follow what others are posting. Consequently, the more posts in the hashtag stream, the more the hashtag community can be considered a community (BRUNS; BURGESS, 2011). From this perspective, the use of hashtags may also suggest that 
members of a virtual community aim to forge a particular version of reality/society while building a certain image about themselves that distinguishes them from other groups (BOURDIEU, 1979).

In the next section, we will outline the data gathering and data analysis methodology.

\section{Data collection}

To investigate whether and how sarcasm and mock impoliteness may be used to generate humour in hashtags about classism in Brazil, data were taken from Twitter trending topics of 2017 and 2019.

In a previous paper, Oliveira and Carneiro (2018) identified a hashtag used to start a game, which encouraged tweeters to discuss 'what the poor do to survive.' This hashtag was among the Brazilian trending topics in August 2017, together with a similar one, \#thingspoorpeopledo (\#CoizasQPobreFaz), with the word 'thing' misspelled ('coizas', instead of 'coisas'). In a second data gathering, carried out in March 2019, these hashtags were also popular, which proved this recurrent topic feature in Brazilian Twitter.

Once we identified these hashtags as recurrent trending topics, the further step was to use Twitter search engine to find other hashtags with the keyword 'pobre' (poor) in the same period of time. This search resulted in finding a total of six hashtags about the theme: \#CoisasQuePobreFaz (\#ThingsThatPoorpeopleDdo), \#CoizasQPobreFaz; \#coisaQuePobreFaz (\#ThingPoorPeopleDo), \#pobre (\#poor); \#pobreza (\#poverty), \#pobrezaÉIssoAi (\#thatIsPoverty) and \#pobre (\#poor). 
After we did that, posts available from Twitter search engines were collected as images. In this research phase, over 400 tweets containing hashtags were gathered. Graph 1 summarizes this data gathering step:

\section{Graph 1 - hashtag types per publication frequency on} Twitter

\section{Hashtag frequency}

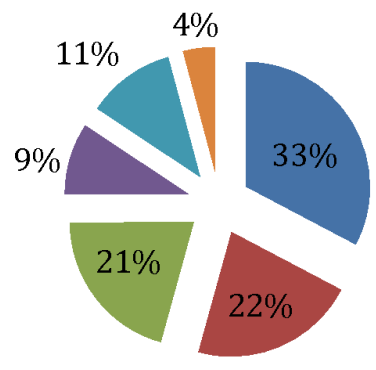

\#coizasqpobrefaz

\#pobrezaeisoaí

\#coisasquepo brefaz

\#coisaquepobrefaz

\#pobre

\#pobreza

Source: By the authors.

After categorizing hashtags per type, we carried a manual analysis to identify the use of impoliteness strategies in the data collected. The examples in the following section display our findings concerning these findings.

\section{Analysis of Twitter posts containing hashtags}

In most of the examples that follow, it is possible to observe how certain social class symbols (GOFFMAN, 1951) characterize social division in Brazil. In Example 1, 'having an iPAD' is assessed as a symbol of social status and as a form 
of conquering social acceptance. Conversely, not having iPAD represents an obstacle for social class emergence: Não ter iPad \#PobrezaÉIssoAi (not having an iPad \#thatIsPoverty). While the post may be associated with the 'generalized negative assumptions about the habits, manners and living standards of the social groups' (KIENPOITNER; STOPFNER, 2017, p. 87), it is also ironic and humorous. Part of the jocular tone is impinged by the hashtag \#PobrezaÉIssoAi (\#thatIsPoverty), which employs irony and sarcasm as impoliteness meta-strategies (CULPEPER, 2005).

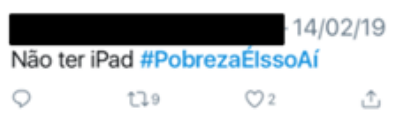

Example 2 also addresses social class division by mocking the upper classes' habits, which lower-class members sometimes imitate. The idea conveyed in Pobre não gasta com academia, ele faz uma! \#CoizasQPobreFaz ('the poor does not pay for the gym, they build their own'! \#ThingsPoorPeopleDo) is reinforced by a picture of a makeshift gym, allegedly used for muscle training.

As Kádár and Mills (2011) argue, working-class people typically coin mocking phrases targeted at over-refined middleclass politeness (or middle-class habits), developing a kind of 'anti-language'. Through this anti-language, norms and values of dominant groups are challenged (KÁDÁR; MILLS, 2011).

In this example, we claim that the deviant spelling of 'coisa' ('coiza' - 'thing') may be associated with this phenomenon. From this point of view, the alternative spelling also addresses (and challenges) the common notion that low-income classes are uneducated, and therefore often display faulty or defective spelling. 
(2)

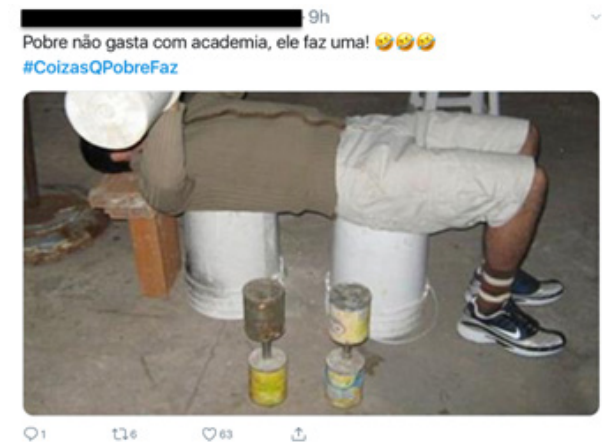

Example 3 employs mockery and sarcasm to ridicule the upper-class members 'pose' (posture), often imitated by lowerclass members. The tweet reads: realidade de quem se acha rico mas às vezes... \#PobrezaÉIssoAi só mantendo a pose!!!!! (the reality of those who believe to be rich, but... \#ThisIsPoverty just keeping the pose!!!!). The tweet's sarcastic tone also serves to assess upper-class members as arrogant or snobbish.

Furthermore, the picture accompanying the post in Example 3 also connects to an upper-class female member stereotype: blonde, slim, blue-eyed, sophisticated, and wearing make-up. These elements help reinforce the clear-cut categorization of social class in Brazil. Contrasting emerges from the inevitable association between the picture and the low-income class female members stereotype, typically depicted as colored, dirty, poorly dressed, and rude. Furthermore, Example 3 also alludes to the 'lower-classes living conditions stereotype by showing unpaved streets and filthy surroundings. 
(3)

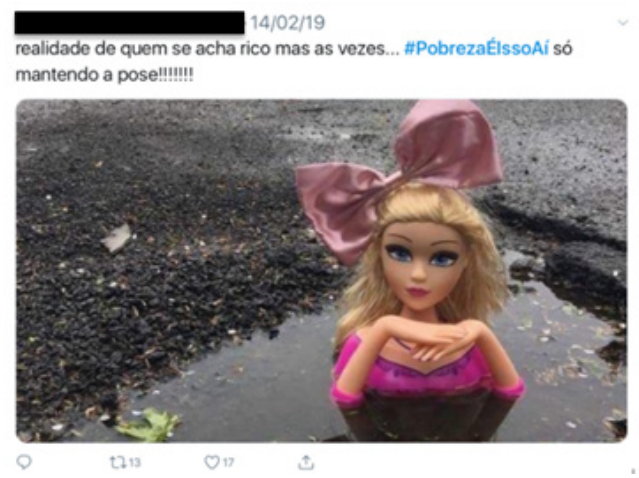

Example (4) suggests that low-income people are used to saving money by keeping it in jars and not at banks, as upperclass members would do. The picture accompanying the post reinforces this notion, while it also conveys the idea of untidiness and scarcity, commonly associated with low-income classes. The post reads: guardar dinheiro em um pote \#PobrezaÉIssoAi (keeping money in a jar \#ThatIsPoverty). Despite being offensive and impolite, in the sense that it relates to negative emotions such as shame and humiliation (CULPEPER, 2005), the post, as well as the hashtag accompanying it, turns out to be playful. The irony lies primarily in the interpersonal exchange tone, marked by the membership to a community of practice prompted by a tag (MILLS, 2015; KÁDÁR; MILLS, 2011).

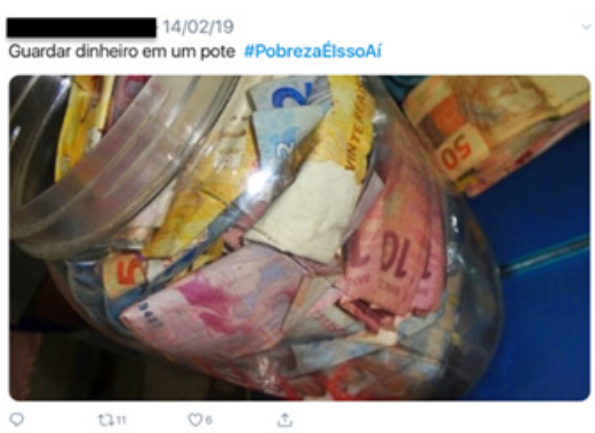


Example 5 leads to the implicated conclusion that lowincome class members do not usually tidy their rooms, as upper classes commonly do. The post reads: Falar 'Não repara na bagunça não.' \#CoizasQPobreFaz (Saying 'do not mind the mess.' \#ThingsPoorPeopleDo). Once again, the post and the accompanying picture serve to express irony and sarcasm targeted to social class stereotypes in Brazil. Furthermore, they also serve as a strategy to enrich in-group solidarity (CULPEPER, 1996) since they bring together members that similarly assess (or mock) social class division.

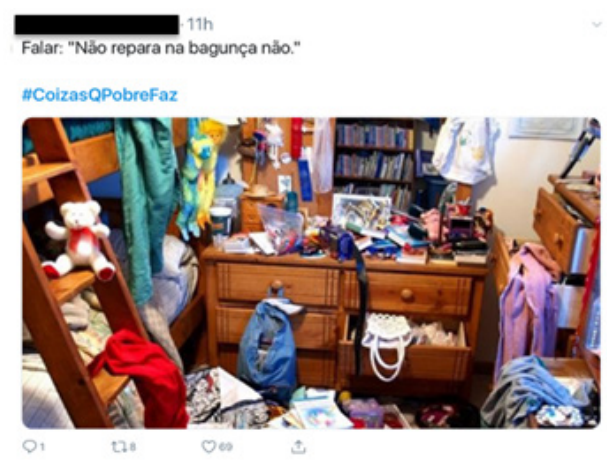

Example 6 reads Dias de glória é coisa de gladiador, pobre só tem dias de luta mesmo \#pobre \#luta \#choraoeterno (glory days are for gladiators; poor people only get the fight. \#Poor \#fight \#eternalCrying), and it deems low-income class members as 'unfortunate' for being unable to 'succeed in life', despite their constant struggle for social emergence. While the post sarcastically relates to 'active yet subtle discrimination' by social class in Brazil (LOVELL, 2006, p. 53), it also employs mockery as a form of untrue offense. Hence, impoliteness is used to play a ritualized linguistic game (LABOV, 1971), reinforcing bonds within a community of practice intended to unveil classism in Brazil. 
In our data, we also found examples in which the tweeter herself ridiculed her material condition, clearly expressing selfmockery. In Example 7, the tweeter explicitly places herself as a lower-class member. She published: To Twitando mas to sem $3 g$ \#pobre \#lisa (I'm tweeting but without 3G \#poor \#broken). By doing so, she mocks herself and other community members who cannot afford easy Internet access.

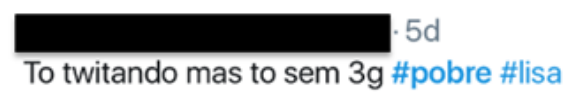

As one can see in the discussed examples in this section, the hashtag \#poor and its variants were mainly employed in posts that criticized classism in Brazil. Along these lines, the analyzed tweets made sarcastic remarks about low-income classes' habits and living conditions, often regarded as badly-mannered, rude, or uncivilized. While doing this, they also related to the notion of ideology as a 'pejorative ring' (EAGLETON, 2014, p. 11), suggesting a distorted perspective that affects our perception of social groups. Furthermore, the posts analyzed also shed light on the notion that certain status symbols help maintain social class division and impede class members from falling or rising social ranks (GOFFMAN, 1951). 


\section{Final remarks}

This research examined Brazilian posts on Twitter that employed sarcastic language apparently intended to disparage low-income classes (pobres). Conversely, our findings also showed that these posts represented a kind of verbal reaction to classism and the dominant ideology (KIENPOITNER; STOPFNER, 2017). Notably, through humor and mockery (CULPEPER, 2005; CULPEPER; HARDAKER, 2017), the posts containing hashtags conveyed a sense of in-group solidarity to an on-line community put together through the same type of hashtag (MILLS, 2015; YANG et al., 2012). This community engaged in a humorous discussion about social issues, more particularly, about classism.

This study reaffirms the notion that the discursivecultural dimension is always crucial to determining what is considered impolite and aggressive in a particular community of practice. For this reason, the hashtags analyzed prompted a dual interpretation: they served as strategies to reinforce social stigmatization in Brazilian society, communicating stereotypes about lower classes' language and habits while operating as a form of transgression by using sarcastic language and their accompanying pictures.

Finally, while believing we have attempted to connect mockery, linguistic impoliteness, and classism to the use of hashtags in Brazilian Twitter, we also understand that the topic is vast and should be placed under further scrutiny. From this perspective, an investigation of classism and ideology manifestations in different social media and platforms and further examination of this topic on Internet forums may be considered 
an additional step to broaden research in this field.

\section{References}

BLITVICH, P. G. C. Globalization, transnational identities, and conflict talk: the super-diversity and complexity of the Latino identity. Journal of Pragmatics, Amsterdam, v. 134, p. 120133, 2018.

BOURDIEU, P. La distinction: critique sociale du jugement. Paris: Les Éditions de Minuit, 1979.

BOUSFIELD, D. Impoliteness in interaction. Amsterdam: John Benjamins Publishing, 2008.

BROWN, P.; LEVINSON, S. Politeness: some universals in language use. Cambridge: Cambridge University Press, 1987.

BRUNS, A.; BURGESS, J. E. The use of Twitter hashtags in the formation of ad hoc publics. In: 6TH EUROPEAN CONSORTIUM FOR POLITICAL RESEARCH (ECPR) GENERAL CONFERENCE 2011. Proceedings [...]. New York, 2011, p. 89-104.

CRYSTAL, D. Internet Linguistics. A Student Guide. New York: Routledge, 2011.

CULPEPER, J. Impoliteness and entertainment in the television quiz show: The Weakest Link. Journal of Politeness Research, Berlin, v. 1, n. 1, p. 35-72, 2005.

CULPEPER, J. Politeness and impoliteness. Pragmatics of society, Berlin, v. 5, p. 393-467, 2011.

CULPEPER, J. Towards an anatomy of impoliteness. Journal of pragmatics, Amsterdam, v. 25, n. 3, p. 349-367, 1996

CULPEPER, J.; HARDAKER, C. Impoliteness. In: CULPEPER, J.; KÁDÁR, D. (ed.). The Palgrave Handbook of Linguistic 
(Im) politeness. London: Palgrave Macmillan, 2017. p. 199225.

CULPEPER, J.; HAUGH, M.; KÁDÁR, D. Z. (org.). The Palgrave handbook of linguistic (im) politeness. London: Palgrave Macmillan, 2017.

CUNHA, G. X.; TOMAZI, M. M. O uso agressivo da linguagem em uma audiência: uma abordagem discursiva e interacionista para o estudo da im/polidez. Calidoscópio, São Leopoldo, v. 17, n. 2, p. 297-319, 2019.

EAGLETON, T. Ideology. New York: Routledge, 2014.

FREYRE, G. Casa-grande \& senzala. Rio de Janeiro: Livraria José Olympio, 1973.

GOFFMAN, E. La mise en scène de la vie quotidienne: les relations en public. v. 2. Paris: Les éditions de minuit, 1973.

GOFFMAN, E. Symbols of class status. The British Journal of Sociology, London, v. 2, n. 4, p. 294-304, 1951.

GRAINGER, K. "We're not in a club now": a neo-Brown and Levinson approach to analyzing courtroom data. Journal of Politeness Research, Berlin, v. 14, n. 1, p. 19-38, 2018.

HAUGH, M. Impoliteness and taking offence in initial interactions. Journal of Pragmatics, Amsterdam, v. 86, p. 3642, 2015.

KÁDÁR, D. Z.; HAUGH, M. Understanding politeness. Cambridge: Cambridge University Press, 2013.

KÁDÁR, D. Z.; MILlS, S. (org.). Politeness in East Asia. Cambridge: Cambridge University Press, 2011.

KIENPOINTNER, M.; STOPFNER, M. Ideology and (Im) politeness. In: CULPEPER, J.; KÁDÁR, D. (org.). The Palgrave Handbook of Linguistic (Im)politeness. London: Palgrave Macmillan, 2017. p. 61-87.

LABOV, W. Language in the inner city: Studies in the black 
English vernacular. Oxford: Blackwell, 1972.

LABOV, W. The study of language in its social context. Advances in the Sociology of Language, Berlin, v. 1, p. 152-216, 1971.

LAYTON, M.; SMITH, E. Is it race, class, or gender? the sources of perceived discrimination in Brazil. Latin American Politics and Society, Cambridge, v. 59, n. 1, p. 52-73, 2017.

LEECH, G. The pragmatics of politeness. Oxford: Oxford University Press, 2014.

LOVELL, P. Race, Gender, and Work in São Paulo, Brazil, 1960-2000. Latin American Research Review, Pittsburgh, v. 41, n. 3, p. 63-87, 2006

MILLS, S. Gender and Politeness. Cambridge: Cambridge University Press, 2003.

MILLS, S. Language, culture and politeness. SHARIFIAN, F. (Org.). The Routledge handbook of language and culture. Abingdon: Routledge, 2015. p. 129-140.

MILLS, S.; KÁDÁR, D. Z. (org.). Politeness in East Asia. Cambridge: Cambridge University Press, 2011.

OLIVEIRA, A. L. A. M.; CARNEIRO, M. M. \# CAGUEI: agressividade no twitter. Revista (Con) textos Linguísticos, Vitória, v. 12, n. 22, p. 7-20, 2018.

OSTERMANN, A. C. Comunidades de prática: gênero, trabalho e face. In: HEBERLE, V. M.; OSTERMANN, A. C.; FIGUEIREDO, D. C. (org.) Linguagem e gênero no trabalho, na mídia e em outros contextos. Florianópolis: Editora da UFSC, 2006. p. 15-47.

SILVA, G. M. Folk Conceptualizations of Racism and Antiracism in Brazil and South Africa. Ethnic and Racial Studies, Abington, v. 35, n. 3, p. 506-522, 2012.

SOTO, L. M.; ARANCIBIA, M. C. Descortesía ideológica y construcción de imagen social em uma entrevista polémica. 
Cadernos de Linguagem e Sociedade, Brasília, v. 18, n. 3, p. 6-32, 2017.

SCOTT, K. The pragmatics of hashtags: Inference and conversational style on Twitter. Journal of Pragmatics, Amsterdam, v. 81, p. 8-20, 2015.

STARBIRD, K.; PALEN, L. Voluntweeters: Self-organizing by digital volunteers in times of crisis. In: PROCEEDINGS OF THE SIGCHI CONFERENCE ON HUMAN FACTORS IN COMPUTING SYSTEMS. 2011. Proceedings [...]. London, 2011. p. 1071-1080.

TELLES, E.; BAILEY, S. Understanding Latin American Beliefs About Racial Inequality. American Journal of Sociology, Chicago, v. 118, n. 6, p. 1559-1595, 2013.

YANG, L. et al. We know what@ you\# tag: does the dual role affect hashtag adoption? In: 21ST INTERNATIONAL CONFERENCE ON WORLD WIDE WEB. Proceedings [...]. London, 2012. p. 261-270. 